Int. J. Dev. Biol. 54: 397-407 (2010)

doi: $10.1387 / \mathrm{ijdb} .082758 \mathrm{ea}$

\title{
Estrogen regulation of placental angiogenesis and fetal ovarian development during primate pregnancy
}

\author{
EUGENE D. ALBRECHT ${ }^{1, *}$ and GERALD J. PEPE ${ }^{2}$ \\ ${ }^{1}$ Department of Obstetrics, Gynecology and Reproductive Sciences, Center for Studies in Reproduction, \\ University of Maryland School of Medicine, Baltimore, Maryland and \\ ${ }^{2}$ Department of Physiological Sciences, Eastern Virginia Medical School, Norfolk, Virginia, USA
}

\begin{abstract}
During human and nonhuman primate pregnancy, an extensive blood vessel network is established within the villous placenta to support fetal growth and follicles develop within the fetal ovary to provide a pool of oocytes for reproductive function in adulthood. These two important developmental events occur in association with a progressive increase in placental estrogen production and levels. This review will describe the developmental processes required for placental vascularization and fetal follicular maturation and recent studies which show that estrogen has an important role in regulating these events.
\end{abstract}

KEY WORDS: placenta, estrogen, angiogenesis, fetus, ovary

\section{Introduction}

During human and nonhuman primate pregnancy, the placenta produces large amounts of estrogen. Estrogen has a fundamentally important role in regulating the sequence of events leading to the initiation of labor (Gibb et al., 2006), the biosynthesis of progesterone (Albrecht and Pepe, 1990), and placental transfer mechanisms that modulate maturation of the fetal hypothalamic-pituitary-adrenocortical axis (Pepe and Albrecht, 1995). Although the latter developmental processes culminate in late gestation, relatively little is known about the significance of placental trophoblast estrogen during earlier stages of pregnancy. An extensive vascular network begins to develop within the villous placenta early in pregnancy and fetal ovarian follicular development is initiated at midgestation. Both of these developmental events continue throughout gestation, coinciding with a marked increase in placental estrogen biosynthesis. The present review describes recent studies which show that estrogen has an essential role in promoting placental villous blood vessel development and fetal ovarian folliculogenesis during primate pregnancy.

\section{Estrogen regulation of placental villous angiogenesis}

\section{Placental villous angiogenesis and expression of angioregulatory growth factors}

During primate pregnancy, the placenta simultaneously accesses maternal blood and develops a vascular network within the villous stroma for the transport of nutrients critical for fetal growth and development. Successful placentation and embryonic/fetal growth and development are dependent upon optimal vascularization of the villous placenta (Kingdom et al., 2000; Reynolds et al., 2005; Torry et al., 2002; Wulff et al., 2003), and thus a deficiency in placental villous vascularization has been associated with spontaneous abortion and embryonic death (Shore et al., 1997). Development of the vascular system within the placental villous stroma is initiated by in situ differentiation of endothelial cells from fetal mesenchymal precursors or angioblasts, i.e. vasculogenesis, and formation of new capillaries from existing microvessels, i.e. angiogenesis, resulting in tertiary villi equipped with an arterio-capillary-venous system (Charnock-Jones et al., 2004; Kaufman et al., 2004; Mayhew et al., 2004; Wulff et al., 2003; Demir et al., 2006). Angiogenesis results from increased interendothelial cell permeability, proteolysis of the basal lamina, endothelial cell proliferation, and directed migration or chemotaxis of endothelial cells. Newly-formed microvessels then undergo elongation, remodeling and maturation, via investment of endothelial cells with periendothelial vascular smooth muscle cells and pericytes. Studies correlating placental vascular endothelial growth factor (VEGF) expression with villous angiogenesis suggest that VEGF and its tyrosine kinase receptors are essential for establishing the capillary bed within the developing intermedi-

Abbreviations used in this paper: VEGF, vascular endothelial growth factor.

\footnotetext{
*Address correspondence to: Eugene D. Albrecht. Department of Obstetrics, Gynecology and Reproductive Sciences, Center for Studies in Reproduction, University of Maryland School of Medicine, Baltimore, Maryland, USA. e-mail: ealbrech@umaryland.edu
} 
ate villi during the first half of human pregnancy (Reynolds and Redmer, 2001; Ahmed et al., 2000). VEGF is the most potent mitogen known to stimulate angiogenesis (Ferrara and DavisSmith, 1997; Ferrara, 2004) and it induces endothelial cell permeability leading to extravasation of plasma proteins that provide a matrix for endothelial cell migration (Brown et al., 1997; Dvorak et al., 1999). VEGF is encoded from a single gene by differential exon splicing and expressed as 5 isoforms of $121,145,165,189$, and 206 amino acids, however, the 121 and 165 species exhibit the greatest angiogenic activity. Inactivation of the VEGF gene in transgenic mice results in embryonic vascular defects and lethality (Carmeliet et al., 1996). VEGF binds to the fms-like tyrosine kinase (flt-1) and kinase-insert domain containing (KDR/flk-1) receptors (deVries et al., 1992). Both receptors are required for vascular development, since homozygous KDR/flk-1 or flt-1 defective mice die in utero as a result of defects in haematopoietic and endothelial cell development (Shalaby et al., 1995) and vascular channel organization (Fong et al., 1995).

Two other proteins, angiopoietin (Ang) -1 and -2, work in concert with VEGF in signaling vascular morphogenesis by binding to the Tie- 2 receptor. In Tie- 2 null mice endothelial cells assemble into tubes, but vessels lack branching networks, encapsulation by periendothelial support cells and organization (Dumont et al., 1994; Sato et al., 1995). It has been proposed (Suri et al., 1996; Hanahan, 1997; Maisonpierre et al., 1997; Thurston et al., 1999) therefore, that VEGF, Ang-1 and Ang-2 interact to control vascular morphogenesis, remodeling, and maturation. Initially, VEGF binds to its receptors to stimulate endothelial cell migration/proliferation and capillary tube formation. Ang-1 then binds to Tie-2 to promote association of endothelial cells with periendothelial vascular smooth muscle cells and pericytes to mature newly-formed blood vessels. Ang2 , by an antagonistic action on Tie-2, loosens the vessel wall, rendering endothelial cells accessible to VEGF to further promote angiogenesis.

VEGF mRNA and protein are expressed by cytotrophoblasts, syncytiotrophoblast, and Hofbauer macrophage cells of the human placenta (Sharkey et al., 1993; Jackson et al., 1994; Ahmed et al., 1995; Cooper et al., 1995; Clark et al., 1996) and the flt- 1 and KDR/flk-1 VEGF receptors are expressed on placental vascular endothelial cells (Clark et al., 1996, Barleon et al., 1994). Ang-1 and Ang-2 are also expressed by placental cytotrophoblasts and the syncytiotrophoblast and Tie-2 is expressed in the vascular endothelium during human pregnancy (Goldman-Wohl et al., 2000; Leach et al., 2002; Zhang et al., 2001; Bussolati et al., 2000), consistent with the proposed role of these angioregulatory growth factors on placental vascular development.

In addition to the angiostimulatory growth hormones, endogenous inhibitors, e.g. soluble truncated flt-1, exist and have important roles via sequestration in modulating bioavailability of VEGF (Ahmad and Ahmed, 2005; Maynard et al., 2003). Increasing levels of soluble flt-1 occur and may be involved in abnormal conditions of pregnancy, e.g. preeclampsia (Ahmad and Ahmed, 2004; Levine et al., 2004; Thadhani et al., 2004). Although angiogenesis is of paramount importance to fetalplacental development, and the VEGF-Ang-1/-2 system is expressed in the placenta, very little is known about the regulation of placental VEGF, Ang-1 and Ang-2 expression during human pregnancy.

\section{Estrogen regulation of placental villous VEGF expression and angiogenesis}

Estrogen stimulates angiogenesis in and expression of VEGF by the uterus during the normal reproductive cycle. Thus, in the rat uterus estradiol rapidly increased vascular permeability, edema, and endothelial cell mitosis (Astwood, 1938; Friederici, 1967). Estradiol also increased VEGF mRNA levels in vivo in the uterus of nonpregnant rats (Cullinan-Bove and Koos, 1993; Hyder et al., 2000), sheep (Reynolds et al., 1998a) rhesus monkeys (Nayak et al., 2002) and baboons (Niklaus et al., 2002, 2003; Albrecht et al., 2003; Aberdeen et al., 2008) and in vitro in human endometrial cells (Charnock-Jones et al., 1993; Shifren et al., 1996). This stimulatory action of estrogen required the estrogen receptors, because chronic estrogen treatment induced angiogenesis in the uterus of normal but not estrogen receptor-null mice (Johns et al., 1996). Moreover, estrogen enhanced uteroplacental blood flow (Magness and Rosenfeld, 1989; Magness, 1998) and microvascular volume (Reynolds et al., 1998b) in sheep, presumably as a result of enhanced angiogenesis as well as vasodilation. While estrogen has been shown to have a major role in stimulating VEGF and blood vessel growth in the uterus during the reproductive cycle, recent studies show that estrogen also has an important role in regulating these processes in the primate placenta.

In a developmental study conducted in the baboon, we showed that villous cytotrophoblasts were a major source of VEGF, and that VEGF mRNA levels increased in parallel with the rise in serum estradiol during advancing stages of pregnancy (Hildebrandt et al., 2001). In contrast, VEGF mRNA levels in the syncytiotrophoblast and cells of the inner villous stroma were relatively low and did not change significantly with advancing gestation. The increase in cytotrophoblast VEGF expression was associated with a progressive increase in blood vessel density and the percentage of stromal tissue occupied by blood vessels within the villous placenta during advancing baboon pregnancy. The increase in placental blood vessel density in the baboon is consistent with the increase in vascularization previously shown during the second half of gestation in the choronic villi of the human (Stoz et al., 1988) and fetal cotyledons of the sheep (Borowicz et al., 2007) placenta.

To determine whether estrogen regulates the latter important aspects of placental development, placental VEGF mRNA levels and vascularization were assessed during the first third of pregnancy in baboons in which endogenous estrogen production and levels were suppressed by administration of the aromatase inhibitor letrozole or prematurely increased by administration of the aromatizable $\mathrm{C}_{19}$-steroid androstenedione (Albrecht et al., 2004). Androstenedione treatment increased serum estradiol levels 3fold, placental villous cytotrophoblast VEGF mRNA levels over 2fold and placental stromal vessel density by $50 \%$ when compared with that in untreated animals. In contrast, administration of letrozole decreased serum estradiol levels and placental villous cytotrophoblast but not stromal cell VEGF mRNA expression by $75 \%$, effects prevented by concomitant administration of letrozole and estradiol. An acute temporal study further showed that villous cytotrophoblast VEGF mRNA levels were markedly increased within $2 \mathrm{~h}$ of estradiol administration to baboons early in preg- 
nancy, while VEGF expression in cells of the inner villous stroma was unaltered (Robb et al., 2004). The estrogen-induced increase in VEGF was specific for VEGF 121 and 165, which are the most abundantly expressed VEGF A species and which are thought to regulate early aspects of angiogenesis (Dvorak et al., 1999).

In contrast to the increase in placental villous cytotrophoblast VEGF expression induced by estrogen in early pregnancy, trophoblast VEGF mRNA levels and vessel density within the villous placenta were not changed by suppressing estrogen production/ levels by letrozole administration throughout the second half of baboon pregnancy (Robb et al., 2007). Moreover, the stimulatory effect of estrogen on VEGF expression shown in the first half of gestation was specific for villous cytotrophoblasts, since VEGF mRNA levels within cells of the inner villous stroma were unaltered by estrogen administration or estrogen deprivation. Thus, the regulatory impact of estrogen on placental VEGF expression and vessel density appears to be established during the first half of gestation and exerted specifically on villous cytotrophoblasts.

\section{Estrogen regulation of placental villous Ang-1 and Ang-2 expression}

In contrast to the increase in cytotrophoblast VEGF mRNA levels with advancing pregnancy, placental villous cytotrophoblast and syncytiotrophoblast Ang-1 mRNA levels and protein localization exhibited a progressive decline in association with the rise in estrogen levels between early, mid and late baboon gestation (Babischkin et al., 2007). Moreover, as noted with VEGF, Ang-1 expression within the villous stroma remained relatively constant. Ang-1 mRNA determined by in situhybridization was also expressed in high level within the cytotrophoblast and syncytiotrophoblast of the human placenta, and as in the baboon expression decreased in late gestation (Dunk et al., 2000). Unlike the decline in Ang-1 expression, Ang-2 mRNA levels within the placental villous trophoblast and stroma were not changed during advancing baboon pregnancy (Babischkin et al., 2007) and exhibited only a small increase with advancing human pregnancy (Dunk etal., 2000). In contrast, others have shown that Ang-2 mRNA levels assessed in whole placental villous tissue decreased with advancing human (Geva et al., 2002) and marmoset (Wulff et al., 2002) gestation. Therefore, although there is considerable agreement about the cellular localization and expression of Ang-1 and Ang-2 during the course of human, baboon, and marmoset pregnancy, differences occur when whole placental tissue is analyzed, indicating the importance in quantifying levels of angioregulatory or other molecules within specific cell populations isolated from heterogenous tissue such as the placenta.

To determine whether placental Ang-1 and Ang-2 are regulated by estrogen, Ang-1 and Ang-2 mRNA and protein were determined in the placenta of baboons during the first third of gestation after prematurely elevating estrogen by chronic administration of estrogen precursor androstenedione or acute administration of estradiol (Albrecht et al., 2008). Chronic androstenedione treatment increased serum estradiol levels three-fold and caused a striking decrease in villous cytotrophoblast Ang-1 mRNA to a level that was one-third of that in untreated animals. Within 2 $\mathrm{h}$ of estradiol administration, cytotrophoblast Ang-1 mRNA was decreased to a level one-fifth of that in untreated animals. How- ever, as observed with VEGF, Ang-1 mRNA levels were unaltered by either chronic or acute elevations in estrogen in cells within the villous stroma. Moreover, expression of Ang-2 by cytotrophoblasts or whole villous tissue was unchanged by estrogen treatment (Albrecht et al., 2008). The estrogen- and advancing gestationinduced decline in cytotrophoblast Ang-1 expression is consistent with the concept that placental villous trophoblast Ang-1 expression is suppressed by the progressive elevation in endogenous estrogen during advancing primate pregnancy.

\section{Cell-specific mechanisms underlying estrogen regulation of placental angioregulatory growth factors}

The recent studies described above show that estrogen induced a significant increase in the expression of VEGF and a decrease in expression of Ang-1 by placental villous cytotrophoblasts and/or syncytiotrophoblast, but not cells isolated from the villous stroma, during early baboon pregnancy. The divergent effect of estrogen on placental villous trophoblast angioregulatory factor expression was specific for VEGF and Ang-1, while placental Ang-2 mRNA levels were unaltered. Moreover, the estrogen-induced increase in placental villous VEGF expression was confined to the first half of pregnancy. Interestingly, the increase in VEGF expression by villous cytotrophoblasts was accompanied by an estrogen-induced decrease in extravillous cytotrophoblast VEGF expression in early baboon pregnancy (Bonagura et al., 2008), which may provide the mechanism for estrogen suppression of extravillous trophoblast invasion of the uterine spiral arteries (Albrecht et al., 2006). Collectively, based on these findings it is clear that estrogen differentially regulates placental villous VEGF, Ang-1 and Ang-2 expression in an angioregulatory-, placental cell-, and gestational age-specific manner during primate pregnancy.

Recent observations are consistent with the concept that the regulatory actions of estrogen on placental villous trophoblast VEGF and Ang-1 formation are mediated by the estrogen receptor. Thus, estrogen receptor $\alpha$ and $\beta$ are expressed within the nuclei of placental cytotrophoblasts and the syncytiotrophoblast of the baboon placenta (Pepe et al., 1999; Albrecht et al., 2008; Bonagura et al., 2008), as previously shown in the human trophoblast (Billiar et al., 1997; Bukovsky et al., 2003). Although there are no estrogen receptor consensus sequences within the promoter region of VEGF (Hyder and Stancel, 1999; Mueller et al., 2000 ), estrogen gene regulation is a multifactorial process controlled via interaction between estrogen receptors and transcription factors (Kushner et al., 2000; Bjornstrom and Sjoberg, 2005), notably hypoxia-inducible factor-1, which is recruited along with estrogen receptor $\alpha$ to the VEGF promoter in the rat uterus (Kazi et al., 2005). Therefore, it is possible that the effects of estrogen on placental VEGF expression involve oxygen/hypoxia-mediated (Ahmed et al., 2000) as well as direct actions of estrogen.

The cell-specific divergent effects of estrogen on VEGF expression in cytotrophoblasts within the villous versus extravillous compartment are also exhibited in other estrogen responsive systems. For example, estrogen increased VEGF transcription and cell proliferation in estrogen receptor $\alpha$ - and $\beta$-positive MCF7 and decreased VEGF expression and cell proliferation in estrogen receptor $\alpha$-negative $\beta$-positive MDA-MB breast cancer cells (Coradini et al., 2004; Lee et al., 2004; Stender et al., 2007). This differential regulation may reflect cell-specific presence/ 
absence of estrogen receptor subtypes as well as functional enhancers, co-activators, and/or co-repressors that modulate estrogen-regulated target gene transcription (Hu and Lazer, 2000; Yong and Wong, 2006; Stender et al., 2007) and be particularly manifest in placental trophoblasts which undergo marked cellular differentiation within the villous and extravillous pathways.

\section{Impact on placental villous angiogenesis}

It is likely that the estrogen-induced increase in VEGF, decrease in Ang-1 and maintenance of Ang-2 within the trophoblast discussed above control the unique pattern of neovascularization exhibited within the villous placenta during advancing primate pregnancy. VEGF has a pivotal role in stimulating vascular endothelial cell assembly into capillaries (Ferrara and Gerber, 2001), whereas Ang-1 stimulates vascular endothelial and smooth muscle cell coupling, thereby promoting arteriole-venule vessel formation, maturation and stabilization (Hanahan, 1997; Yancopoulos etal., 2000; Lobov etal., 2002; Visconti etal., 2002). Unopposed, Ang-2 causes vessel breakdown, but in the presence of VEGF Ang-2 appears to render endothelial cells responsive to VEGF (Maisonpierre et al., 1997; Yancopoulos et al., 2000; Visconti et al., 2002), causing angiogenesis and antagonizing the stabilizing effect of Ang-1 (Asahara et al., 1998; Lobov et al., 2002). Thus, the maturation of vessels into arterioles and venules within stem villi in the first half of pregnancy, when estrogen levels are low, may be regulated by elevated levels of trophoblast Ang1 and low levels of VEGF. In the second half of gestation, an extensive highly coiled capillary sinusoidal network is formed and retained within the mature intermediate and terminal villi which comprise over half of the placental villous mass for maximal maternal-fetal exchange (Charnock-Jones etal., 2004; Kaufmann et al., 2004; Mayhew et al., 2004). We propose, as shown in Fig. 1 , that in response to increasing levels of estrogen, the increased expression of VEGF, decreased expression of Ang-1 and sustained levels of Ang-2 by trophoblasts creates an environment for the development and retention of capillaries required for maximal blood exchange within the terminal villi. The estrogen-induced changes in expression of these angioregulatory growth factors by villous cytotrophoblast, along with the proximity of these cells to the inner villous mesenchyme would provide a system for promoting vasculogenesis and thus blood flow within the placenta and, consequently, growth and development of the fetus.

\section{Estrogen regulation of baboon fetal ovarian follicle development}

\section{Formation of ovarian follicles during fetal development}

It is well established that in human and nonhuman primates, formation of the pool of primordial follicles available for reproductive function in adulthood occurs in utero (Rabinovici and Jaffe 1990; Pepe et al., 2006). Thus, following differentiation of the bipotential gonad into an ovary very early in gestation (Simpson and Rajkovic, 1999), presumptive germ cells undergo mitosis (now termed oogonia) and become colonized by proliferating pregranulosa cells (Byskov, 1986; Sawyer et al., 2002). Several oogonia then initiate meiosis to form oocytes which arrest in the diplotene/dictyate phase of prophase I of meiosis. At about midgestation, the pregranulosa cells and oocytes begin to contact each other to form somatic cell-germ

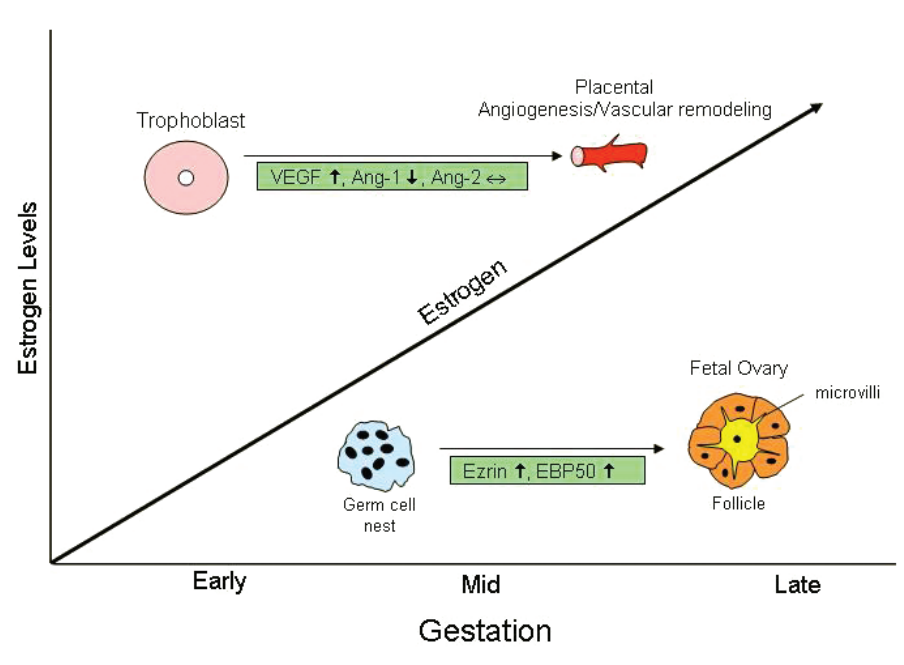

Fig. 1. Estrogen regulation of placental angiogenesis and fetal ovarian development during primate pregnancy.

cell complexes which progressively fuse to form a structure termed a germ cell nest which is encased by a basal lamina. During this period of development, follicles form within the nest and it is presumed that emergence of primordial follicles in the ovarian cortex involves breakdown of the basal lamina of the nest, a process termed germ cell nest breakdown (Sawyer et al., 2002). Finally, primordial follicles formed in utero must develop mechanisms/structures to support their survival for up to 40 years (Pepe et al., 2006). Thus, because the foundation for normal adult reproductive function is established during fetal life (Rabinovici and Jaffe, 1990; Pepe et al., 2006), inadequate ovarian development in utero may impair reproductive potential in the adult. Hence, a more comprehensive understanding of the factors underpinning intrauterine development of the pool of follicles available in adulthood is a prerequisite to managing adult ovarian dysfunction. However, elucidation of fetal ovarian development and its impact on reproductive function and fertility (i.e. programming) requires studies in which invasive experimental paradigms can be performed in utero and ovarian function assessed postnatally, studies which for ethical reasons cannot be performed in humans. Therefore, although the cellular development of the human fetal ovary has been well-characterized (Baker, 1963; van Wagenen and Simpson, 1965), our understanding of the regulation of human fetal ovarian development is limited and based primarily on isolated case reports of genomic defects, morphological characterization of abortuses, serum hormone levels, and in vitro approaches. Consequently, despite significant advances in adult reproductive medicine, infertility/ovarian dysfunction continues to adversely affect a large segment of the female population (Crisponi et al., 2001). For example, a significant number of infertile women exhibit ovarian failure manifest as a deficit in ovarian follicles ranging from complete absence and thus lack of pubertal development, to a reduction in the number of germ cells which collectively comprise the clinical syndrome of premature ovarian failure (Crispoini et al., 2001; Simpson and Rajkovic, 1999; Layman etal., 1998; Beck-Peccoz and Persani, 2006). Therefore, a nonhuman primate model is needed to 
study fetal ovarian development and to translate this information to the human.

\section{Estrogen receptor expression in fetal ovary}

Our laboratories have been instrumental in establishing the baboon as a model for the study of human reproductive endocrinology and as discussed above, showed that estrogen, the maternal and fetal levels of which increase with advancing gestation as in women (Albrecht and Pepe, 1988), plays a central integrative role in regulating fetal-placental development (Albrecht and Pepe, 1999). Like the human, the baboon fetal ovary at midgestation is comprised of numerous germ cell nests containing oocytes and pregranulosa cells but very few primordial follicles and by late gestation is comprised almost exclusively of primordial follicles and very few germ cell nests. Moreover, our laboratories were among the first to show that fetal ovarian follicular development in the baboon was associated with expression of the mRNAs and proteins for estrogen receptor (ER) $\alpha$ and ER $\beta$ (Pepe etal., 2002). Thus, ER $\alpha$ protein was localized to nuclei of surface epithelium and pregranulosa cells but not oocytes on day 100 of gestation and in the surface epithelium and in several but not all granulosa cells of primordial follicles on days 165-180 of gestation (term = day 184). ER $\beta$ was also localized and abundantly expressed in the nuclei of pregranulosa cells on day 100 and extensively expressed in granulosa cells of follicles on day 165 of gestation. Moreover, oocytes obtained from near term fetal ovaries by laser capture microdissection expressed the mRNA for ER $\beta$ but not ER $\alpha$ (Bocca et al., 2008).

\section{Estrogen regulation of fetal ovarian folliculogenesis}

In the adult rat, estrogen regulates several aspects of ovarian function (Richards, 1980; Billig et al., 1983) and male and female $\alpha \beta$ ER knock-out mice are infertile (Couse and Korach, 1999). Therefore, we originally proposed (Pepe et al., 2002) that estrogen regulates fetal ovarian development in utero. To test this hypothesis, follicle development was examined in baboons treated daily on days 100-165 of gestation with the highly specific aromatase inhibitor, letrozole (CGS 20267; Norvartis Pharm AG, Basel Switzerland), which suppressed maternal and fetal estradiol levels by $>95 \%$ or with letrozole and estradiol benzoate which restored estrogen levels in the mother and fetus to $90-120 \%$ and $10 \%-30 \%$ of normal, respectively (Albrecht et al., 2000; Zachos et al., 2002). The incomplete restoration of fetal serum estrogen levels reflects transplacental metabolism of maternally administered estradiol (Albrecht and Pepe, 1990). In estrogen-suppressed baboons, although fetal ovarian weight and expression of $\mathrm{ER} \alpha$ or $\mathrm{ER} \beta$ were not significantly changed, follicle numbers were reduced by $50 \%$ (Zachos et al., 2002), whereas the number of germ cell nests containing pregranulosa cells/oocytes which failed to form follicles as well as follicles which were not released into the ovarian stroma was increased 3-fold. Moreover, whereas most of the follicles in untreated baboons contained oocytes with an intact cytoplasm and appeared healthy, in estrogen depleted fetuses, the number of intact oocytes was markedly reduced. Thus the majority ( $>70 \%$ ) of follicles that formed in estrogendepleted fetuses contained oocytes in which the cytoplasm exhibited vacuolization (i.e. not intact) and were comprised of swollen and less electron-dense mitochondria.

Exposure of the fetus particularly early in gestation to excess androgen has also been shown to disturb fetal ovarian development (Steckler et al., 2005; Manikkam et al., 2006; Abbott et al., 2006). However, because aromatization is blocked and androgen (i.e. androstenedione and testosterone) levels comparably increased in baboons treated with letrozole alone or with estradiol (Zachos et al., 2002) and androgen receptor protein is not detected in the near term baboon fetal ovary (Pepe and Albrecht, unpublished), the suppression of follicle development in estrogen deficient baboons reflects the absence of estrogen and not increased androgen (Pepe et al., 2006). Consistent with our original observations, in aromatase knock-out mice totally devoid of estrogen synthesis, the number of primordial follicles formed was also reduced due to their lack of formation from germ cell nests (Britt et al., 2004).

It also is unlikely that fetal pituitary gonadotrophins regulate primordial follicle development in the primate. Thus, in the baboon (Zachos et al., 2003), as in humans (Reyes et al., 1981; Kaplan and Grumbach, 1976), fetal serum FSH and LH levels increase to a maximum at midgestation (i.e. before follicle formation) and decline steadily thereafter (i.e. during the period of folliculogenesis). Moreover, ovarian folliculogenesis apparently proceeded normally up to week 32 of gestation in human anencephalic fetuses (Baker and Scrimegour, 1980). Although FSH receptor (FSHR) binding and mRNA are detected in the near-term fetal rhesus monkey (Huhtaniemi et al., 1987) and baboon (Zachos et al., 2003), we showed that the reduction in the number of primordial follicles formed in near-term baboon fetuses deprived of estrogen between mid and late gestation was associated with an increase in fetal serum FSH and no change in fetal ovarian FSHR mRNA (Zachos et al., 2003). Finally, in two women with hypogonadism due to a mutation in the FSH $\beta$-subunit gene and thus no detectable $\mathrm{FSH}$, one conceived after induction of ovulation (Matthews etal., 1993), while the other exhibited increased follicle growth (Barnes et al., 2002) after exogenous FSH, indicating that follicles had developed in utero in the absence of FSH (Layman et al., 1998; Themmen and Huhtaniemi, 2000). Collectively, our studies provided the first definitive evidence that development of a stockpile of healthy follicles available for adult ovarian function in the primate is an intrauterine estrogen-dependent event.

In the adult, ovarian function and follicle recruitment are regulated by an interplay between pituitary gonadotrophins, estrogen and various intragonadal autocrine/paracrine factors most notably inhibin and activin (Findlay, 1993; Mather et al., 1997; Cook et al., 2004). Inhibins are composed of an $\alpha$ subunit and one of two $\beta$ subunits, whereas activins are homo/heterodimers of either of the two $\beta$ subunits (Matzuk, 2000 a,b). The action of activins is mediated by interaction at the cell membrane with type I and/or type II receptors (Pangas and Woodruff, 2000) and phosphorylation of a class of substrates collectively known as Smads (Massague, 1998; Zhang and Derynck, 1999), e.g., Smads 2 and 3 which bind to a common mediator Smad 4 that translocates to the nucleus to activate target genes (Lagna et al., 1996). Because a specific receptor for inhibin remains to be characterized (Bernard et al., 2002), inhibins act either by binding $\beta$ subunits to produce an inactive dimmer (i.e. inhibin) and/or binding to the activin receptor to prevent the action of activin (Matzuk, 2000). Therefore, we determined whether the baboon fetal ovary expressed these important functional antagonists and whether expression was altered in association with the decrease 
in follicle formation in estrogen-deprived fetuses. Immunocytochemical and Western blot showed that proteins for activin $\beta A$ and $\beta B$, the activin receptors (Billiar et al., 2003), as well as Smad 2, 3 and 4 (Billiar et al., 2004), were abundantly expressed and localized in oocytes and pregranulosa cells at midgestation and in granulosa cells at term. Moreover, the site of expression and levels of the activin subunits, the activin receptors and Smads 2, 3 and 4 were not altered by development or estrogen-deprivation. In contrast, expression of $\alpha$-inhibin which was minimal in fetal ovaries of untreated baboons at both mid and late gestation, was markedly up-regulated in estrogen-suppressed fetuses in late gestation and detected primarily in pregranulosa cells of germ cell nests and granulosa cells of primordial follicles, an effect prevented when estrogen was restored (Billiar et al., 2003). Therefore, we have proposed that estrogen regulates encapsulation of oocytes by granulosa cells, i.e. folliculogenesis, by controlling the intraovarian activin: inhibin ratio. Consistent with this suggestion, Mayo and colleagues have shown that over-expression of the $\alpha$ inhibin subunit gene in mice in the presence or absence of $\mathrm{FSH}$ caused several ovarian pathologies including development of ovarian cysts (McMullen et al., 2001; Cho et al., 2001).

\section{Estrogen regulation of fetal ovary microvilli formation}

Elegant studies of others have shown that oocytes are dependent upon surrounding granulosa cells for uptake and exchange of metabolic products and thus survival (Eppig, 1979; Heller et al., 1981; Brower and Schultz, 1982). In epithelial cells of the kidney and small intestine, nutrient/substrate exchange is accomplished primarily by microvilli developed and present in large numbers on the cell surface (Lange 2002). Microvilli are present on oocytes of primordial follicles in the human fetal (Gondos et al., 1971; Motta and Makabe, 1982) and adult (Familiari et al., 1993) ovary and in the ovary of adult rats oocytes exhibiting cytoplasmic vacuolization show a marked retraction of their microvilli (Devine et al., 2000). Estrogen has previously been shown to increase development of microvilli in rat pituitary cells (Antalky et al., 1980) and microvilli are disrupted/depleted in ovarian primordial follicles of women undergoing chemotherapy, an effect which is partially prevented by pretreatment with estrogen containing oral contraceptives (Familiari etal., 1993). Therefore, we determined whether estrogen regulates the formation and/or maintenance of oocyte microvilli in the primate fetal ovary and whether development of microvilli by the fetal oocyte is associated with oocyte structural integrity (Zachos et al., 2004).

Oocyte microvilli, examined by transmission electron microscopy, were not detected in the fetal ovary at midgestation but became abundant in primordial follicles by late gestation and were maintained in primordial follicles of the adult ovary. Importantly, oocyte microvilli were minimal in fetal ovaries of baboons depleted of estrogen, but well developed in fetal baboons treated with letrozole and estrogen. Thus, as confirmed by image analysis, the number of microvilli/intact oocyte in estrogen-suppressed fetuses was $56 \%$ lower $(P<0.01)$ than normal and restored by letrozole and estrogen. Similar results were noted when the number of microvilli was expressed per square micrometer oocyte surface area. Moreover, average height of microvilli on intact oocytes of letrozole-treated baboons was $54 \%$ lower $(P<0.01)$ than in baboons untreated or treated with letrozole plus estrogen. Interestingly, no microvilli were detected on the surface of non- intact oocytes in estrogen-suppressed baboons. These results are the first to demonstrate that development of a microvillus brush border by the oocyte of primordial follicles is regulated in utero in the primate fetal ovary by estrogen and support our hypothesis that estrogen regulates fetal ovarian folliculogenesis and development of follicles with healthy oocytes composed of microvilli critical for nutrient uptake and presumably long-term survival.

The biochemical mechanisms by which estrogen regulates oocyte microvilli development in the baboon fetal ovary remain to be elucidated (Pepe et al., 2006). It is well established that ezrin plays an important role in the formation and maintenance of microvilli (Bretscher et al., 1997; Hanzel et al., 1991; Berryman et al., 1993) and thus microvillus structures are completely lost after treatment of cultured epithelial cells with antisense nucleotides that block ezrin formation (Takeuchi et al., 1994; Yonemura et al., 1999). A preponderance of evidence shows that microvillus formation requires movement of ezrin from the cytoplasm to the plasma membrane and binding to membrane phosphatidylinositol4,5-bis-phosphate (PIP2) and phosphorylation of ezrin by intracellular kinases (Fievet et al., 2004 for review). Ezrin phosphate then links to the membrane spanning protein ezrin-binding protein 50 (EBP50), which maintains ezrin phosphate at the membrane (Reczek and Bretscher, 1998) and facilitates binding to f-actin to complete the formation of the microvilli (Fievet et al., 2004). Thus, in association with microvilli breakdown in epithelial cells, ezrin is not phosphorylated and ezrin and EBP50 relocate from the surface of the cell to the cytoplasm (Morales etal., 2004). Ongoing studies in our laboratories suggest that comparable mechanisms are operative in the fetal oocyte and regulated by estrogen. Thus, recently completed studies indicate that ezrin and EBP50 are expressed in the oocyte of primordial follicles in baboon fetal ovary and that cellular localization is modified and thus becomes localized away from the membrane in oocytes of fetal ovaries from estrogen-suppressed baboons (Zachos et al., 2008).

In summary, the baboon fetal ovary expressed ER $\alpha$ and ER $\beta$ and fetal ovarian development was significantly altered in animals in which estrogen had been depleted by administration of an aromatase inhibitor during the second half of gestation and restored by concomitant administration of estradiol. Thus, in the absence of estrogen, follicle numbers were decreased by approximately $50 \%$, whereas the number of germ cell nests comprised of pregranulosa cells and oocytes was increased and associated with a marked upregulation of expression of $\alpha$-inhibin but not activins or the activin receptors and signalling molecules. We also showed that the majority of the follicles that did form in ovaries of estrogen-deprived fetuses appeared unhealthy and contained oocytes with a marked depletion/reduction in microvilli, structures essential for uptake of substrates from surrounding granulosa cells. We propose therefore, as illustrated in Fig. 1, that estrogen regulates formation of the pool of primordial follicles comprised of healthy oocytes essential for adult reproductive function by controlling the formation of microvilli on the oocyte membrane.

\section{Significance}

Finally, the significance of our studies is heightened by studies showing that endocrine disruptors that create either an excess (e.g. diethylstilbestrol) or deficit (e.g. deletion of ER genes; 
increased exposure to environmental factors that bind but do not activate $E R$ ) in estrogen availability/action have profound effects on fetal development (McLachlan, 2001; Guillette and Moore, 2006; Abbott et al., 2006 for review). Moreover, because estrogen receptors are required for maintenance of germ and somatic cells in the postnatal rodent ovary (Couse and Korach, 1999; Couse et al., 1999), it is possible that in cases of estrogen deficiency/ inhibition of estrogen action in human pregnancy there is a risk of impairment of fetal and consequently adult ovarian development either directly and/or secondary to enhanced sensitivity to environmental endocrine disruptors (Vandenbergh, 2003) and/or biohazards which have been shown to accelerate follicular atresia and decrease primordial follicle development in estrogen-deficient but not estrogen-treated prepubertal rats (Thompson et al., 2002). Thus, our studies in the baboon coupled with the corollary work of others demonstrate the need for translational research studies using nonhuman primate models to address impact of estrogen deficiency/impairment of estrogen action and exposure to environmental disruptors in utero on ovarian maturation and fertility in adulthood.

\section{Summary}

It is well established that placental estrogen regulates important developmental events during primate pregnancy, including the production of progesterone, fetal adrenal maturation and the onset of parturition. However, it is clear from the recent studies described in this review, that the marked increase in placental estrogen which occurs during advancing primate pregnancy also promotes the expression of key growth factors necessary for placental villous angiogenesis and development of the pool of healthy follicles within the fetal ovary. Thus, placental estrogen regulates physiological processes required for growth and development of the fetus for extrauterine life and intrauterine programming events crucial to fertility and physiological homeostasis in adulthood. Because the fetus provides the steroid precursors required for estrogen biosynthesis within the placental trophoblast, the fetus ultimately exerts a pivotal role in the maturation of the organ systems essential to self-sufficiency in adulthood.

\section{Acknowledgments}

The studies on baboon pregnancy described in this review were supported by NIH RO1 HD13294 and NIH/NICHD through cooperative agreement U54 HD36207 as part of the Specialized Cooperative Centers Program in Reproduction and Infertility Research.

\section{References}

ABBOTT, D.H., PADMANABHAN, V. and DUMESIC, D.A. (2006). Contributions of androgen and estrogen to fetal programming of ovarian dysfunction. Reprod. Biol. Endocrinol. 4: 17

ABERdeEN, G.W., WIEGAND, S.J., BONAGURA, T.W., PEPE, G.J. and ALBRECHT, E.D. (2008). Vascular endothelial growth factor mediates the estrogen-induced breakdown of tight junctions between and increase in proliferation of microvessel endothelial cells in the baboon endometrium. Endocrino/ogy 149: 6076-6083.

AHMAD, S. and AHMED, A. (2004). Elevated placental soluble vascular endothelial growth factor receptor- 1 inhibits angiogenesis in preeclampsia. Circ. Res. 95: 884-891.

AHMAD, S. and AHMED, A. (2005). Antiangiogenic effect of soluble vascular endothelial growth factor receptor-1 in placental angiogenesis. Endothelium 12:
89-95.

AHMED, A., DUNK, C., AHMAD, S. and KHALIQ, A. (2000). Regulation of placental vascular endothelial growth factor (VEGF) and placenta growth factor (PIGF) and soluble Flt-1 by oxygen: a review. Placenta (Suppl. A)21: S16-S24.

AHMED, A., LI, X.F., DUNK, C., WHITTLE, M.J., RUSHTON, D.I. and ROLLASON, T. (1995). Colocalisation of vascular endothelial growth factor and its flt-1 receptor in human placenta. Growth Factors 12: 235-243.

ALBRECHT, E.D., ABERDEEN, G.W., NIKLAUS, A.L., BABISCHKIN, J.S., SURESCH, D.L. and PEPE, G.J. (2003). Acute temporal regulation of vascular endothelial growth/permeability factor expression and endothelial morphology in the baboon endometrium by ovarian steroids. J. Clin. Endocrinol. Metab. 88: 2844-2852.

ALBRECHT, E.D., ABERDEEN, G.W. and PEPE, G.J. (2000). The role of estrogen in the maintenance of primate pregnancy. Am. J. Obstet. Gynecol. 182: 432438.

ALBRECHT, E.D., BABISCHKIN, J.S. and PEPE, G.J. (2008). Regulation of placental villous angiopoietin-1 and -2 expression by estrogen during early baboon pregnancy. Mol. Reprod. Dev.75: 504-511.

ALBRECHT, E.D., BONAGURA, T.W., BURLEIGH, D.W., ENDERS, A.C. and PEPE, G.J. (2006). Suppression of extravillous trophoblast invasion of uterine spiral arteries by estrogen during early baboon pregnancy. Placenta 27: 483490.

ALBRECHT, E.D. and PEPE, G.J. (1988). Endocrinology of pregnancy. In: NonHuman Primates in Perinatal Research (Eds. Y.W. Brans and T.J. Kuehl). John Wiley and Sons, NY pp. 13-78.

ALBRECHT, E.D. and PEPE, G.J. (1990). Placental steroid hormone biosynthesis in primate pregnancy. Endocr. Rev. 11: 124-150.

ALBRECHT, E.D. and PEPE, G.J. (1999). Central integrative role of oestrogen in modulating the communication between the placenta and fetus that results in primate fetal-placental development. Placenta 20: 129-139.

ALBRECHT, E.D., ROBB, V.A. and PEPE, G.J. (2004). Regulation of placental vascular endothelial growth/permeability factor expression and angiogenesis by estrogen during early baboon pregnancy. J. Clin. Endocrinol. Metab. 89 : 5803-5809.

ANTAKLY, T., PELLETIER, G., ZEYTINOGLU, F. and LABRIE, F. (1980). Changes of cell morphology and prolactin secretion induced by 2 - $\mathrm{Br}-\alpha$-ergocryptine, estradiol, and thyro $\neq$ tropin-releasing hormone in rat anterior pituitary cells in culture. J. Cell. Biol. 86: 377-387.

ASAHARA, T., CHEN, D., TAKAHASHI, T., FUJIKAWA, K., KEARNEY, M., MAGNER, M., YANCOPOULOS, G.D. and ISNER, J.M. (1998). Tie2 receptor ligands, angiopoietin-1 and angiopoietin-2, modulate VEGF-induced postnata neovascularization. Circ. Res. 83: 233-240.

ASTWOOD, E. (1938). A six-hour assay for the quantitative determination of estrogen. Endocrinology 23: 25-31.

BABISCHKIN, J.S., SURESCH, D.L., PEPE, G.J. and ALBRECHT, E.D. (2007) Differential expression of placental villous angiopoietin-1 and -2 during early, $\mathrm{mid}$, and late baboon pregnancy. Placenta 28: 212-218.

BAKER, T.G. (1963). A quantitative and cytological study of germ cells in human ovaries. Proc. Roy. Soc. B. 158: 417-433.

BAKER, T.G. and SCRIMGEOUR, J.B. (1980). Development of the gonad in norma and anencephalic human fetuses. J. Reprod. Fertil. 60: 193-199.

BARLEON, B., HAUSER, S., SCHOLLMANN, C., WEINDEL, K., MARME, D. YAYON, A. and WEICH, H.A. (1994). Differential expression of the two VEGF receptors flt-1 and KDR in placenta and vascular endothelial cells. J. Cell. Biochem. 54: 56-66.

BARNES, R.B., NAMNOUM, A.B., ROSENFIELD, R.L. and LAYMAN, L.C. (2002) The role of $\mathrm{LH}$ and FSH in ovarian androgen secretion and ovarian follicular development: clinical studies in a patient with isolated FSH deficiency and multicystic ovaries. Human Reprod. 17: 88-91.

BECK-PECCOZ, P. and PERSANI, L. (2006). Premature ovarian failure. Orphanet. J. Rare Dis. 1: 9.

BERNARD, D.J., CHAPMAN, S.C. and WOODRUFF, T.K. (2002). Minireview: Inhibin binding protein (InhBP/p120), betaglycan, and the continuing search for the inhibin receptor. Mol. Endocrinol. 16: 207-212.

BERRYMAN, M., FRANCK, Z. and BRETSCHER, A. (1993). Ezrin is concentrated 
in the apical microvilli of a wide variety of epithelial cells whereas moesin is found primarily in endothelial cells. J. Cel/ Sci. 105: 1025-1043.

BILLIAR, R.B., PEPE, G.J. and ALBRECHT, E.D. (1997). Immunocytochemical identification of the oestrogen receptor in the nuclei of human placental syncytiotrophoblasts. Placenta 18: 365-370.

BILLIAR, R.B., ST. CLAIR, J.B., ZACHOS, N.C., BURCH, M.G., ALBRECHT, E.D. and PEPE, G.J. (2004). Localization and developmental expression of the activin signal transduction proteins Smads 2, 3, and 4 in the baboon fetal ovary. Biol. Reprod. 70: 586-592.

BILLIAR, R.B., ZACHOS, N.C., BURCH, M.G., ALBRECHT, E.D. and PEPE, G.J. (2003). Up-regulation of $\alpha$-inhibin expression in the fetal ovary of estrogensuppressed baboons is associated with impaired fetal ovarian folliculogenesis. Biol. Reprod. 68: 1989-1996.

BILLIG, H., FURUTA, I. and HSUEH, A.J.W. (1993). Estrogens inhibit and androgens enhance ovarian granulosa cell apoptosis. Endocrinology 133: 2204 2212

BOCCA, S.M., BILLIAR, R.B., ALBRECHT, E.D. and PEPE, G.J. (2008). Oocytes of baboon fetal primordial ovarian follicles express estrogen receptor $\beta$ mRNA. Endocrine, 33: 254-260.

BONAGURA, T.W., PEPE, G.J., ENDERS, A.C. and ALBRECHT, E.D. (2008). Suppression of extravillous vascular endothelial growth factor expression and uterine spiral artery invasion by estrogen during early baboon pregnancy. Endocrinology 49: 2078-5087

BOROWICZ, P.P., ARNOLD, D.R., JOHNSON, M.L., GRAZUL-BILSKA, A.T., REDMER, D.A. and REYNOLDS, L.P. (2007). Placental growth throughout the last two thirds of pregnancy in sheep: vascular development and angiogenic factor expression. Biol. Reprod. 76: 259-267.

BRETSCHER, A., RECZEK, D. and BERRYMAN, M. (1997). Ezrin: a protein requiring conformational activation to link microfilaments to the plasma membrane in the assembly of cell surface structures. J. Cel/ Sci. 110: 3011-3018.

BRITT, K.L., SAUNDERS, P.K., MCPHERSON, S.J., MISSO, M.L., SIMPSON, E.R. and FINDLAY, J.K. (2004). Estrogen actions on follicle formation and early follicle development. Biol. Reprod. 71: 1712-1723.

BROWER, P.T. and SCHULTZ, R.M. (1982). Intercellular communication between granulosa cells and mouse oocytes: existence and possible nutritional role during oocyte growth. Dev. Biol. 90: 144-153.

BROWN, L.F., DETMAR, M., CLAFFEY, K., NAGY, J.A., FENG, D., DVORAK, A.M and DVORAK, H.F. (1997). Vascular permeability factor/vascular endothelial growth factor: a multifunctional angiogenic cytokine. EXS. 79: 233-269.

BUKOVSKY, A., CAUDLE, M.R., CEKANOVA, M., FERNANDO, R.I., WIMALASENA, J., FOSTER, J.S., HENLEY, D.C. and ELDER, R.F. (2003). Placental expression of estrogen receptor beta and its hormone binding variantcomparison with estrogen receptor alpha and a role for estrogen receptors in asymmetric division and differentiation of estrogen-dependent cells. Reprod. Biol. Endocrinol. 1: 36-56.

BUSSOLATI, B., PERKINS, J., SHAMS, M., RHAMAN, M., NIJJAR, S., QUI, Y., KNISS D., DUNK, C., YANCOPOULOS, G. and AHMED, A. (2000). Angiopoietin1 and angiopoietin-2 are differentially expressed during placental development and stimulate trophoblast proliferation, migration and release of nitric oxide. $J$. Soc. Gynecol. Invest. (Suppl) 7: 158A.

BYSKOV, A.G. (1986). Differentiation of mammalian embryonic gonad. Physiol. Rev. 66: 71-117.Bjornstrom L, Sjoberg M 2005 Mechanisms of estrogen receptor signaling: convergence of genomic and nongenomic actions on target genes. Mol. Endocrinol. 19: 833-842.

CARMELIET, P., FERREIRA, V., BREIER, G., POLLEFEYT, S., KIECKENS, L., GERTSENSTEIN, M., FAHRIG, M., VANDENHOECK, A., HARPAL, K., EBERHARDT, C., DECLERCQ, C., PAWLING, J., MOONS, L., COLLEN, D., RISAU, W. and NAGY, A. (1996). Abnormal blood vessel development and lethality in embryos lacking a single VEGF allele. Nature 380: 435-439.

CHARNOCK-JONES, D.S., KAUFMANN, P. and MAYHEW, T.M. (2004). Aspects of human fetoplacental vasculogenesis and angiogenesis. I. Molecular Regulation. Placenta 25: 103-113.

CHARNOCK-JONES, D.S., SHARKEY, A.M., RAIPUT-WILLIAMS, J., BURCH, D., SCHOFIELD, J.P., FOUNTAIN, S.A., BOOCOCK, C.A. and SMITH, S.K (1993). Identification and localization of alternatively spliced mRNAs for vascular endothelial growth factor in human ulterus and estrogen regulation in endometrial carcinoma cell lines. Biol. Reprod. 48: 1120-1128.
CHO, B-N., MCMULLEN, M.L., PEI, L. and YATES, J. (2001). Reproductive deficiencies in transgenic mice expressing the rat inhibin $\alpha$-subunit gene. Endocrinology 142: 4994-5004.

CLARK, D.E., SMITH, S.K., SHARKEY, A.M. and CHARNOCK-JONES, D.S (1996). Localization of VEGF and expression of its receptors flt and KDR in human placenta throughout pregnancy. Human Reprod. 11: 1090-1098.

COOK, R.W., THOMPSON, T.B., JARDETZKY, T.S. and WOODRUFF, T.K. (2004). Molecular biology of inhibin action. Semin. Reprod. Med. 22: 269-276.

COOPER, J.C., SHARKEY, A.M., MCLAREN, J., CHARNOCK-JONES, D.S. and SMITH, S.K. (1995). Localization of vascular endothelial growth factor and its receptor, flt, in human placenta and decidua by immunohistochemistry. $J$. Reprod. Fertil. 105: 205-213.

CORADINI, D., PELLIZZARO, C., SPERANZA, A. and DAIDONE, M.G. (2004) Hypoxia and estrogen receptor profile influence the responsiveness of human breast cancer cells to estradiol and antiestrogens. Cell. Mol. Life Sci. 61: 76-82.

COUSE, J.F., HEWITT, S.C., BUNCH, D.O., SAR, M., WALKER, V.R., DAVIS, B.J and KORACH, K.S. (1999). Postnatal sex reversal of the ovaries in mice lacking estrogen receptors $\alpha$ and $\beta$. Science 286: 2328-2331.

COUSE, J.F. and KORACH, K.S. (1999). Estrogen receptor null mice: What have we learned and where will they lead us? Endocr. Rev. 20: 358-417.

CRISPONI, L., DEIANA, M., LOI, A., CHIAPPE, F., UDA, M., AMATI, P., BISCEGLIA, L., ZELANTE, L., NAGARAJA, R., PORCU, S., RISTALDI, M.S., MARZELLA, R., ROCCHI, M., NICOLINO, M., LIENHARDT-ROUSSIE, A., NIVELON, A., VERLOES, A., SCHLESSINGER, D., GASPARINI, P., BONNEAU, D., CAO, A and PILIA, G. (2001). The putative forkhead transcription factor FOXL2 is mutated in blepharophimosis/ptosis/epicanthus inversus syndrome. Nat. Genet. 27: 159-166

CULLINAN-BOVE, K. and KOOS, R.D. (1993). Vascular endothelial growth factor/ vascular permeability factor expression in the rat uterus: rapid stimulation by estrogen correlates with estrogen-induced increases in uterine capillary permeability and growth. Endocrinology 133: 829-837.

DEMIR, R., KAYISLI, U.A., CAYLI, S. and HUPPERTZ, B. (2006). Sequential steps during vasculogenesis and angiogenesis in the very early human placenta. Placenta 27: 535-539.

DEVINE, P.J., PAYNE, C.M., MCCUSKEY, M.K. and HOYER, P.B. (2000). Ultrastructural evaluation of oocytes during atresia in rat ovarian follicles. Biol. Reprod. 63: 1245-1252.

DE VRIES, C., ESCOBEDO, J.A., UENO, H., HOUCK, K., FERRARA, N. and WILLIAMS, L.T. (1992). The fms-like tyrosine kinase, a receptor for vascular endothelial growth factor. Science 255: 989-991.

DUMONT, D.J., GRADWOHL, G.I., FONG, G.H., PURI, M.C., GERTSENSTEIN M., AUERBACH, A. and BREITMAN, M.L. (1994). Dominant-negative and targeted null mutations in the endothelial receptor tyrosine kinase, tek, revea a critical role in vasculogenesis of the embryo. Genes Dev. 8: 1897-1909.

DUNK, C., SHAMS, M., NIJJAR, S., RHAMAN, M., QIU, Y.,.BUSSOLATI, B. and AHMED, A. (2000). Angiopoietin-1 and angiopoietin-2 activate trophoblast Tie2 to promote growth and migration during placental development. Am. J. Pathol. 156:2185-2199.

DVORAK, H.F., NAGY, J.A., FENG, D., BROWN, L.F. and DVORAK, A.M. (1999) Vascular permeability factor/vascular endothelial growth factor and the significance of microvascular hyperpermeability in angiogenesis. Curr. Top. Microbiol. Immunol. 237: 97-132.

EPPIG, J.J. (1979). A comparison between oocyte growth in coculture with granulosa cells and oocytes with granulosa cell-oocyte junctional contact maintained in vitro. J. Exp. Zool. 209: 345-353.

FAMILIARI, G., CAGGIATI, A., NOTTOLA, S.A., ERMINI, M., DI BENEDETTO, M.R. and MOTTA, P.M. (1993). Ultrastructure of human ovarian primordial follicles after combination chemotherapy for Hodgkin's disease. Human Reprod. 8: $2080-2087$

FERRARA, N. (2004). Vascular endothelial growth factor: Basic science and clinical progress. Endocr. Rev. 25: 581-611.

FERRARA, N. and DAVIS-SMYTH, T. (1999). The biology of vascular endothelia growth factor. Endocr. Rev. 18: 4-25.

FERRAR, N. and GERBER, H.P. (2001). The role of vascular endothelial growth factor in angiogenesis. Acta. Haematol. 106: 148-156.

FIEVET, B.T., GAUTREAU, A., ROY, C., DEL, M.L., MANGEAT, P., LOUVARD, D. 
and ARPIN, M. (2004). Phosphoinositide binding and phosphorylation act sequentially in the activation mechanism of ezrin. J. Cell Biol. 164: 653-659.

FINDLAY, J.K. (1993). An update on the roles of inhibin, activin, and follistatin as local regulators of folliculogenesis. Biol. Reprod. 48: 15-23.

FONG, G.H., ROSSANT, J., GERTENSTEIN, M. and BREITMAN, M. (1995). Role of flt-1 receptor tyrosine kinase in regulating the assembly of vascular endothelium. Nature 376: 66-70.

FRIEDERICI, H.H. (1967). The early response of uterine capillaries to estrogen stimulation. Lab. Invest. 17: 322-324.

GEVA, E., GINZINGER, D.G., ZALOUDEK, C.J., MOORE, D.H., BYRNE, A. and JAFFE, R.B. (2002). Human placental vascular development: vasculogenic and angiogenic (branching and nonbranching) transformation is regulated by vascular endothelial growth factor-A, angiopoietin-1, and angiopoietin-2. J. Clin. Endocrinol. Metab. 87: 4213-4224.

GIBB, W., LYE, S.J. and CHALLIS, J.R.G. (2006). Parturition. In: Physiology of Reproduction, Neill JD, ed. Academic Press, pp 2925-2974.

GOLDMAN-WOHL, D.S., Ariel, I., GREENFIELD, C., LAVY, Y. and YAGEL, S. (2000). Tie-2 and angiopoietin-2 expression at the fetal-maternal interface: a receptor ligand model for vascular remodeling. Mol. Human. Reprod. 6: 81-87.

GONDOS, B., BHIRALEUS, P. and HOBEL, C.J. (1971). Ultrastructural observations on germ cells in human fetal ovaries. Am. J. Obstet. Gynecol. 110: 644652.

GUILLETTE, L.J., Jr and MOORE, B.C. (2006). Environmental contaminants, fertility, and multioocytic follicles: a lesson from wildlife? Semin. Reprod. Med. 24: 134-141.

HANAHAN, D. (1997). Signaling vascular morphogenesis and maintenance. Science $277:$ 48-50.

HANZEL, D., REGGIO, H., BRETSCHER, A., FORTE, J.G. and MANGEAT, P. (1991). The secretion-stimulated $80 \mathrm{~K}$ phosphoprotein of parietal cells is ezrin, and has properties of a membrane cytoskeletal linker in the induced apical microvilli. EMBO J. 10: 2363-2373

HELLER, T., CAHILL, D.M. and SCHULTZ, R.M. (1981). Biochemical studies of mammalian oogenesis: Metabolic cooperation between granulosa cells and growing mouse oocytes. Dev. Biol. 84: 455-464.

HILDEBRANDT, V.A., BABISCHKIN, J.S., KOOS, R.D., PEPE, G.J. and ALBRECHT, E.D. (2001). Developmental regulation of vascular endothelial growth/permeability factor messenger ribonucleic acid levels in and vascularization of the villous placenta during baboon pregnancy. Endocrinology 142: 2050-2057.

HU, X. and LAZAR, M.A. (2000). Transcriptional repression by nuclear hormone receptors. Trends Endocrinol. Metab. 11: 6-10.

HUHTANIEMI, I.T., YAMAMOTO, M., RANTA, T., JALKANEN, J. and JAFFE, R.B. (1987). Follicle-stimulating hormone receptors appear earlier in the primate fetal testis than in the ovary. J. Clin. Endocrinol. Metab. 65: 1210-1214.

HYDER, S.M., HUANG, J.C., NAWAZ, Z., BOETTGER-TONG, H., MAKELA, S. CHIAPPETTA, C. and STANCEL, G.M. (2000). Regulation of vascular endothelial growth factor expression by estrogens and progestins. Environ. Health Perspect. 108: 785-790.

HYDER, S.M. and STANCEL, G.M. (1999). Regulation of angiogenic growth factors in the female reproductive tract by estrogens and progestins. Mol. Endocrinol. 13:806-811.

JACKSON, M.R., CARNEY, E.W, LYE, S.J. and KNOX RITCHIE, J.W. (1994). Localization of two angiogenic growth factors (PDECGF and VEGF) in human placentae throughout gestation. Placenta 15: 341-353.

JOHNS, A., FREAY, A.D., FRASER, W., KORACH, K.S. and RUBANYI, G.M. (1996). Disruption of estrogen receptor gene prevents 17ß-estradiol-induced angiogenesis in transgenic mice. Endocrinology 137: 4511-4513.

KAPLAN, S.L. and GRUMBACH, M.M. (1978). Pituitary and placental gonadotropins and sex steroids in the human and subhuman primate fetus. J. Clin. Endocrinol. Metab. 7: 487-511.

KAUFMANN, P., MAYHEW, T.M. and CHARNOCK-JONES, D.S. (2004). Aspects of human fetoplacental vasculogenesis and angiogenesis. II. Changes during normal pregnancy. Placenta 25: 114-126.

KAZI, A.A., JONES, J.M. and KOOS, R.D. (2005). Chromatin immunoprecipitation analysis of gene expression in the rat uterus in vivo: estrogen-induced recruitment of both estrogen receptor $\alpha$ and hypoxia-inducible factor 1 to the vascular endothelial growth factor promoter. Mol. Endocrinol. 19: 2006-2019.

KINGDOM, J., HUPPERTZ, B., SEAWARD, G. and KAUFMAN, P. (2000). Development of the placental villous tree and its consequences for fetal growth. Eur. J. Obstet. Gynecol. Reprod. Biol. 92: 35-43.

KUSHNER, P.J., AGARD, D., FENG, W.J., LOPEZ, G., SCHIAU, A., UHT, R., WEBB, P. and GREENE, G. (2000). Oestrogen receptor function at classical and alternative response elements. Novartis Found. Symp. 230: 20-26

LANGE, K. (2002). Role of microvillar cell surfaces in the regulation of glucose uptake and organization of energy metabolism. Am. J. Physiol. Cell Physiol. 282: C1-26.

LAGNA, G., HATA, A., HEMMATI-BRIVANLOU, A. and MASSAGUE, J. (1996). Partnership between DPC4 and SMAD proteins in TGF- $\beta$ signalling pathways. Nature 383: 832-836.

LAYMAN, L.C., MADE, S., COHEN, D.P., JIN, M. and XIE, J. (1998). The Finnish follicle-stimulating hormone receptor gene mutation is rare in North American women with 46,XX ovarian failure. Fertil. Steril. 69: 300-302.

LEACH, L., BABAWALE, M.O., ANDERSON, M. and LAMMIMAN, M. (2002) Vasculogenesis, angiogenesis and the molecular organization of endothelia junctions in the early human placenta. J. Vasc. Res. 39: 246-259.

LEE, J.E., CHUNG, K.W., HAN, W., KIM, S.W., KIM, S.W., SHIN, H.J., BAE, J.Y and $\mathrm{NOH}, \mathrm{D} . \mathrm{Y}$. (2004). Effect of estrogen, tamoxifen and epidermal growth factor on the transcriptional regulation of vascular endothelial growth factor in breast cancer cells. Anticancer Res. 24: 3961-3964.

LEVINE, R.J., MAYNARD, S.E., QIAN, C., LIM, K.H., ENGLAND, L.J., YU, K.F., SCHISTERMAN, E.F., THADHANI, R., SACHS, B.P., EPSTEIN, F.H., SIBAI, B.M., SUKHATME, V.P. and KARUMANCHI, S.A. (2004). Circulating angiogenic factors and the risk of preeclampsia. N. Engl. J. Med. 350: 672-683.

LOBOV, I.B., BROOKS, P.C. and LANG, R.A. (2002). Angiopoietin-2 displays VEGF-dependent modulation of capillary structure and endothelial cell survival in vivo. Proc. Natl. Acad. Sci. USA 99: 11205-11210.

MAGNESS, R.R. (1998). Maternal cardiovascular and other physiological responses to the endocrinology of pregnancy. In The Endocrinology of Pregnancy (Ed. F.W. Bazer). Totowa; Humana Press: 507-539.

MAGNESS, R.R. and ROSENFELD, C.R. (1989). Local and systemic estradiol17ß: effects on uterine and systemic vasodilation. Am. J. Physiol. 256: E536E542.

MAISONPIERRE, P.C., SURI, C., JONES, P.F., BARTUNKOVA, S., WIEGAND, S.J., RADZIEJEWSKI, C., COMPTON, D., MCCLAIN, J., ALDRICH, T.H. PAPADOPOULOS, N., DALY, T.J., DAVIS, S., SATO, T.N. and YANCOPOULOS, G.D. (1997). Angiopoietin-2, a natural antagonist for Tie2 that disrupts in vivo angiogenesis. Science 277: 55-60.

MANIKKAM, M., STECKLER, T.L., WELCH, K.B., INSKEEP, E.K. and PADMANABHAN, V. (2006). Fetal programming: prenatal testosterone treatment leads to follicular persistence/luteal defects; partial restoration of ovarian function by cyclic progesterone treatment. Endocrinology 147: 1997-2007.

MASSAGUE, J. (1998). TGF- $\beta$ signal transduction. Annu. Rev. Biochem. 67: 753 791.

MATHER, J.P., MOORE, A. and LI, R.H. (1997). Activins, inhibins, and follistatins: further thoughts on a growing family of regulators. Proc. Soc. Exp. Biol. Med. 215: 209-222.

MATTHEWS, C.H., BORGATO, S., BECK-PECCOZ, P., ADAMS, M., TONE, Y., GAMBINO, G., CASAGRANDE, S., TEDESCHINI, G., BENEDETTI, A. and CHATTERJEE, V.K. (1993). Primary amenorrhea and infertility due to a mutation in the $\beta$-subunit of follicle-stimulating hormone. Nat. Genet. 5: 83-86.

MATZUK, M.M. (2000). In search of binding-identification of inhibin receptors. Endocrinology 141: 2281-2284

MATZUK, M.M. (2000). Revelations of ovarian follicle biology from gene knockou mice. Mol. Cell Endocrinol. 163: 61-66.

MAYHEW, T.M., CHARNOCK-JONES, D.S. and KAUFMANN, P. (2004). Aspects of human fetoplacental vasculogenesis and angiogenesis. III. Changes in complicated pregnancies. Placenta 25: 127-139.

MAYNARD, S.E., MIN, J.Y., MERCHAN, J., LIM, K.H., LI, J., MONDAL, S. LIBERMANN, T.A., MORGAN, J.P., SELLKE, F.W., STILLMAN, I.E., EPSTEIN, F.S., SUKHATME, V.P. and KARUMANCHI, S.A. (2003). Excess placental soluble fms-like tyrosine kinase 1 (sFlt1) may contribute to endothelial dysfunction, hypertension, and proteinuria in preeclampsia. J. Clin. Invest. 111: 649 
658.

MCLACHLAN, J.A. (2001). Environmental signaling: what embryos and evolution teach us about endocrine disrupting chemicals. Endocr. Rev. 22: 319-341.

MCMULLEN, M.L., CHO, B-N., YATES, J. and MAYO, K.E. (2001). Gonadal pathologies in transgenic mice expressing the rat inhibin $\alpha$-subunit. Endocrinology 142: 5005-5014.

MORALES, F.C., TAKAHASHI, Y., KREIMANN, E.L. and GEORGESCU, M.M. (2004). Ezrin-radixin-moesin (ERM)-binding phosphoprotein 50 organizes ERM proteins at the apical membrane of polarized epithelia. Proc. Natl. Acad. Sci. USA 101: 17705-17710.

MOTTA, P.M. and MAKABE, S. (1982). Development of the ovarian surface and associated germ cells in the human fetus. A correlated study by scanning and transmission electron microscopy. Cell Tissue Res. 226: 493-510.

MUELLER, M.D., VIGNE, J.L., MINCHENKO, A., LEBOVIC, D.I., LEITMAN, D.C. and TAYLOR, R.N. (2000). Regulation of vascular endothelial growth factor (VEGF) gene transcription by estrogen receptors alpha and beta. Proc. Natl. Acad. Sci. USA 97: 10972-10977.

NAYAK, N.R. and BRENNER, R.M. (2002). Vascular proliferation and vascular endothelial growth factor expression in the rhesus macaque endometrium. $\mathrm{J}$. Clin. Endocrinol. Metab. 87: 1845-1855.

NIKLAUS, A.L., ABERDEEN, G.W., BABISCHKIN, J.S., PEPE, G.J. and ALBRECHT, E.D. (2003). Effect of estrogen on vascular endothelial growth/permeability factor expression by glandular epithelial and stromal cells in the baboon endometrium. Biol. Reprod. 68: 1997-2004.

NIKLAUS, A.L., BABISCHKIN, J.S., ABERDEEN, G.W., PEPE, G.J. and ALBRECHT, E.D. (2002). Expression of vascular endothelial growth/permeability factor by endometrial glandular epithelial and stromal cells in baboons during the menstrual cycle and after ovariectomy. Endocrinology 143: 4007-4017.

PANGAS, S.A. and WOODRUFF, T.K. (2000). Activin signal transduction pathways. Trends Endocrinol. Metab. 11: 309-314.

PEPE, G.J. and ALBRECHT, E.D. (1995). Actions of placental and fetal adrenal steroid hormones in primate pregnancy. Endocr. Rev. 16: 608-648.

PEPE, G.J., BILLIAR, R.B. and ALBRECHT, E.D. (2006). Regulation of baboon fetal ovarian folliculogenesis by estrogen. Mol. Cell. Endocrinol. 247: 41-46.

PEPE, G.J., BILLIAR, R.B., LEAVITT, M.G., ZACHOS, N.C., GUSTAFSSON, J.A. and ALBRECHT, E.D. (2002). Expression of estrogen receptor $\alpha$ and $\beta$ in the baboon fetal ovary. Biol. Reprod. 66: 1054-1060.

PEPE, G.J., DAVIES, W.A., DONG, K.W., LUO, H. and ALBRECHT, E.D. (1999). Cloning of the $11 \beta$-hydroxysteroid dehydrogenase $(11 \beta-H S D)$ gene in the baboon: effects of estradiol on promoter activity of $11 \beta-H S D-1$ and -2 in placental JEG-3 cells. Biochim. Biophys. Acta. 144: 101-110.

RABINOVICI, J. and JAFFE, R.B. (1990). Development and regulation of growth and differentiated function in human and subhuman primate fetal gonads. Endocr. Rev. 11: 532-557.

RECZEK, D. and BRETSCHER, A. (2001). Identification of EPI64, a TBC/rabGAP domain-containing microvillar protein that binds to the first PDZ domain of EBP50 and E3KARP. J. Cell Biol. 153: 191-206.

REYES, F.I., FAIMAN, C. and WINTER, J.S.D. (1981). Development of the regulatory mechanisms of the hypothalamic-pituitary-gonadal system in the human fetus: The chorionic-hypothalamic-pituitary-gonadal axis. In: FetalEndocrinology (Eds. M.J. Novy, and J.A. Resko). Academic Press, NY, pp. 285-302.

REYNOLDS, L.P., BOROWICZ, P.P., VONNAHME, K.A., JOHNSON, M.L., GRAZUL-BILSKA, A.T., WALLACE, J.M., CATON, J.S. and REDMER, D.A. (2005). Current Topic - Animal models of placental angiogenesis. Placenta 26: 689-708.

REYNOLDS, L.P., KIRSCH, J.F., KRAFT, K.C., KNUTSON, D.L., MCCLAFLIN, W.J. and REDMER, D.A. (1998b). Time-course of the uterine response to estradiol-17 $\beta$ in ovariectomized ewes: uterine growth and microvascular development. Biol. Reprod. 59: 606-612.

REYNOLDS, L.P., KIRSCH, J.D., KRAFT, K.C. and REDMER, D.A. (1998a). Timecourse of the uterine response to estradiol-17 $\beta$ in ovariectomized ewes: expression of angiogenic factors. Biol. Reprod. 59: 613-620.

REYNOLDS, L.P. and REDMER, D.A. (2001). Angiogenesis in the placenta. Biol. Reprod. 64: 1033-1040.

RICHARDS, J.S. (1980). Maturation of ovarian follicles, actions and interactions of pituitary and ovarian hormones on follicular cell differentiation. Physiol. Rev.60: 51-89.

ROBB, V.A., ALBRECHT, E.D. and PEPE, G.J. (2007). Placental villous vascular endothelial growth factor expression and vascularization after estrogen suppression during the last two-thirds of baboon pregnancy. Endocrine 31: 260267.

ROBB, V.A., PEPE, G.J. and ALBRECHT, E.D. (2004). Acute temporal regulation of placental vascular endothelial growth/permeability factor expression in baboons by estrogen. Biol. Reprod. 71: 1694-1698.

SATO, T.N., TOZAWA, Y., DEUTSCH, U., WOLBRUG-BUCHHOLZ, K., FUJIWARA, Y., GENDRON-MAGUIRE, M., GRIDLEY, T., WOLBURG, H., RISAU, W. and QIN, Y. (1995). Distinct roles of the receptor tyrosine kinases Tie-1 and Tie-2 in blood vessel formation. Nature 376: 70-74.

SAWYER, H.R., SMITH, P., HEATH, D.A., JUENGEL, J.L., WAKEFIELD, S.J. and MCNATTY, K.P. (2002). Formation of ovarian follicles during fetal development in sheep. Biol. Reprod. 66: 1134-1150.

SHALABY, F., ROSSANT, J., YAMAGUCHI, T.P., GERTSENSTEIN, M., WU, X., BREITMAN, M.L. and SCHUH, A.C. (1995). Failure of blood-island formation and vasculogenesis in flk-1-deficient mice. Nature 376: 62-70

SHARKEY, A.M., CHARNOCK-JONES, D.S., BOOCOCK, C.A., BROWN, K.D. and SMITH, S.K. (1993). Expression of mRNA for vascular endothelial growth factor in human placenta. J. Reprod. Fertil. 99: 609-615.

SHIFREN, J.L., TSENG, J.F., ZALOUDEK, C.J., RYAN, I.P., MENG, Y.G., FERRARA, N., JAFFE, R.B. and TAYLOR, R.N. (1996). Ovarian steroid regulation of vascular endothelial growth factor in the human endometrium: implications for angiogenesis during the menstrual cycle and in the pathogenesis of endometriosis. J. Clin. Endocrinol. Metab. 81: 3112-3118.

SHORE, V.H., WANG, T.H., WANG, C.L., TORRY, R.J., CAUDLE, M.R. and TORRY, D.S. (1997). Vascular endothelial growth factor, placenta growth factor and their receptors in isolated human trophoblast. Placenta 18: 657-665.

SIMPSON, J.L. and RAJKOVIC, A. (1999). Ovarian differentiation and gonadal failure. Am. J. Med. Genet. 89: 186-200.

STECKLER, T., WANG, J., BARTOL, F.F., ROY, S.K. and PADMANABHAN, V. (2005). Fetal programming: prenatal testosterone treatment causes intrauterine growth retardation, reduces ovarian reserve and increases ovarian follicular recruitment. Endocrinology 146: 3185-3193.

STENDER, J.D., FRASOR, J., KOMM, B., CHANG, K.C.N., KRAUS, W.L. and KATZENELLENBOGEN, B.S. (2007). Estrogen-regulated gene networks in human breast cancer cells: involvement of E2F1 in the regulation of cell proliferation. Mol. Endocrinol. 21: 2112-2123.

STOZ, F., SCHUHMANN, R.A. and SCHEBESTA, B. (1988). The development of the placental villus during normal pregnancy: morphometric data base. Arch. Gynecol. Obstet. 244: 23-32.

SURI, C., JONES, P.F., PATAN, S., BATUNKOVA, S., MAISONPIERRE, P.C., DAVIS, S., SATO, T.N. and YANCOPOULOS, G.D. (1996). Requisite role of angiopoietin-1, a ligand for the TIE-2 receptor, during embryonic angiogenesis. Cel/87: 1171-1180.

TAKEUCHI, K., SATO, N., KASAHARA, H., FUNAYAMA, N., NAGAFUCHI, A., YONEMURA, S., TSUKITA, S. and TSUKITA, S. (1994). Perturbation of cell adhesion and microvilli formation by antisense oligonucleotides to ERM family members. J. Cell. Biol. 125: 1371-1384.

THADHANI, R., MUTTER, W.P., WOLF, M., LEVINE, R.J., TAYLOR, R.N., SUKHATME, V.P., ECKER, J. and KARUMANCHI, S.A. (2004). First trimester placental growth factor and soluble fms-like tyrosine kinase 1 and risk for preeclampsia. J. Clin. Endocrinol. Metab. 89: 770-775.

THEMMEN, A.P.N. and HUHTANIEMI, I.T. (2000). Mutations of gonadotropins and gonadotropin receptors: elucidating the physiology and pathophysiology of pituitary-gonadal function. Endocr. Rev. 21: 551-583.

THOMPSON, K.E., SIPES, I.G., GREENSTEIN, B.D. and HOYER, P.B. (2002). $17 \beta$-estradiol affords protection against 4-vinylcyclohexene diepoxide-induced ovarian follicle loss in Fischer-344 rats. Endocrinology 143: 1058-1065.

THURSTON, G., SURI, C., SMITH, K., MCCLAIN, J., SATO, T.N., YANCOPOULOS, G.D. and MCDONALD, D.M. (1999). Leakage-resistant blood vessels in mice transgenically over expressing angiopoietin-1. Science 286: 2511-2514.

TORRY, R.J., SCHWARTZ, J.S. and TORRY, D.S. (2002). Vascularization of the placenta. In Cardiovascular molecular morphogenesis: assembly of the vascu- 
lature and its regulation. (Ed. R.J. Tomanel). New York: Springer-Verlag: 239273.

VANDENBERGH, J.G. (2003). Prenatal hormone exposure and sexual variation. Am. Scientist $91: 218-225$.

VAN WAGENEN, G. and SIMPSON, M.E. (1965). Embryology of the Ovary and Testis in Homo sapiens and Macaca mulatta. Yale University Press, New Haven, CT.

VISCONTI, R.P., RICHARDSON, C.D. and SATO, T.N. (2002). Orchestration of angiogenesis and arteriovenous contribution by angiopoietins and vascular endothelial growth factor (VEGF). Proc. Natl. Acad. Sci. USA 99:8219-8224.

WULFF, C., WIEGAND, M., KREIENBERG, R. and FRASER, H.M. (2003). Angiogenesis during primate placentation in health and disease. Reproduction 126: 569-577.

WULFF, C., WILSON, H., DICKSON, S.E., WIEGAND, S.J. and FRASER, H.M (2002). Hemochorial placentation in the primate: expression of vascular endothelial growth factor, angiopoietins, and their receptors throughout pregnancy. Biol. Reprod. 66: 802-812.

YANCOPOULOS, G.D., DAVIS, S., GALE, N.W., RUDGE, J.S., WIEGAND, S.J. and HOLASH, J. (2000). Vascular-specific growth factors and blood vessel formation. Nature 407: 242-248.

YONEMURA, S., TSUKITA, S. and TSUKITA, S. (1999). Direct involvement of ezrin/radixin/moesin (ERM)-binding membrane proteins in the organization of microvilli in collaboration with activated ERM proteins. J. Cel/ Biol. 145: $1497-$
1509.

YONG, H.G. and WONG, J. (2006). The corepressors silencing mediator of retinoid and thyroid hormone receptor and nuclear receptor corepressor are involved in agonist and antagonist-regulated transcription by androgen receptor. Mol. Endocrinol. 20: 1048-1060.

ZACHOS, N.C., BILLIAR, R.B., ALBRECHT, E.D. and PEPE, G.J. (2002). Developmental regulation of baboon fetal ovarian maturation by estrogen. Biol. Reprod. 67: 1148-1156.

ZACHOS, N.C., BILLIAR, R.B., ALBRECHT, E.D. and PEPE, G.J. (2003). Developmental regulation of follicle stimulating hormone receptor mRNA expression in the baboon fetal ovary. Biol. Reprod. 68: 1911-1917.

ZACHOS, N.C., BILLIAR, R.B., ALBRECHT, E.D. and PEPE, G.J. (2004). Regulation of oocyte microvilli development in the baboon fetal ovary by estrogen. Endocrinology 145: 959-966.

ZACHOS, N.C., BILLIAR, R.B., BURCH, M.G., ALBRECHT, E.D. and PEPE, G.J. (2008). Regulation of expression of microvillus membrane proteins by estrogen in baboon fetal ovarian oocytes. Biol. Reprod. 79: 1160-1168.

ZHANG, E.G., SMITH, S.K., BAKER, P.N. and CHARNOCK-JONES, D.S. (2001) The regulation and localization of angiopoietin-1, -2 , and their receptor Tie2 in normal and pathologic human placentae. Molecular Med. 7: 624-635.

ZHANG, Y. and DERYNCK, R. (1999). Regulation of Smad signalling by protein associations and signalling crosstalk. Trends Cell Biol. 9: 274-279. 


\section{Further Related Reading, published previously in the Int. J. Dev. Biol.}

See our recent Special Issue Epigenetics \& Development edited by Saadi Khochbin and Stefan Nonchev at: http://www.ijdb.ehu.es/web/contents.php?vol=53\&issue=2-3

See Special Issue Pattern Formation edited by Michael K. Richardson and Cheng-Ming Chuong at: http://www.ijdb.ehu.es/web/contents.php?vol=53\&issue=5-6

The contribution of Roberto Montesano to the study of interactions between epithelial sheets and the surrounding extracellular matrix

Domenico Ribatti

Int. J. Dev. Biol. (2010) 54: 1-6 (doi: 10.1387/ijdb.082727dr)

Revisiting old vaginal topics: conversion of the Müllerian vagina and origin of the "sinus" vagina

Yi Cai

Int. J. Dev. Biol. (2009) 53: 925-934

A critical role for myoglobin in zebrafish development

Danielle H. Vlecken, Janwillem Testerink, Elisabeth B. Ott, Philippe A. Sakalis, Richard T. Jaspers and Christoph P. Bagowski Int. J. Dev. Biol. (2009) 53: 517-524

Puzzles of mammalian fertilization - and beyond

J. Michael Bedford

Int. J. Dev. Biol. (2008) 52: 415-426

An activating mutation in the PDGF receptor-beta causes abnormal morphology in the mouse placenta

Camilla Looman, Tong Sun, Yang Yu, Agata Zieba, Aive Ahgren, Ricardo Feinstein, Henrik Forsberg, Carina Hellberg, Carl-Henrik Heldin, Xiao-Qun Zhang, Karin Forsberg-Nilsson, Nelson Khoo, Reinald Fundele and Rainer Heuchel

Int. J. Dev. Biol. (2007) 51: 361-370

A simple in vivo approach to investigate invasive trophoblast cells Juan A. Arroyo, Toshihiro Konno, Darya C. Khalili and Michael J. Soares Int. J. Dev. Biol. (2005) 49: 977-980

Control of reproduction by Polycomb Group complexes in animals and plants Anne-Elisabeth Guitton and Frederic Berger

Int. J. Dev. Biol. (2005) 49: 707-716

Commitment of hematopoietic stem cells in avian and mammalian embryos: an ongoing story

Françoise Dieterlen-Lièvre

Int. J. Dev. Biol. (2005) 49: 125-130

Changes in the placenta and in the rat embryo caused by the demethylating agent 5azacytidine.

M Vlahovic, F Bulic-Jakus, G Juric-Lekic, A Fucic, S Maric and D Serman

Int. J. Dev. Biol. (1999) 43: 843-846

Transgenic mice ubiquitously expressing human placental alkaline phosphatase (PLAP): an additional reporter gene for use in tandem with beta-galactosidase (lacZ).

M J Skynner, D J Drage, W L Dean, S Turner, D J Watt and N D Allen

Int. J. Dev. Biol. (1999) 43: 85-90

Involvement of the proto-oncogene c-ets 1 and the urokinase plasminogen activator during mouse implantation and placentation.

D Grevin, J H Chen, M B Raes, D Stehelin, B Vandenbunder and X Desbiens

Int. J. Dev. Biol. (1993) 37: 519-529

The human placenta becomes haemochorial at the 13th week of pregnancy.

J M Foidart, J Hustin, M Dubois and J P Schaaps

Int. J. Dev. Biol. (1992) 36: 451-453

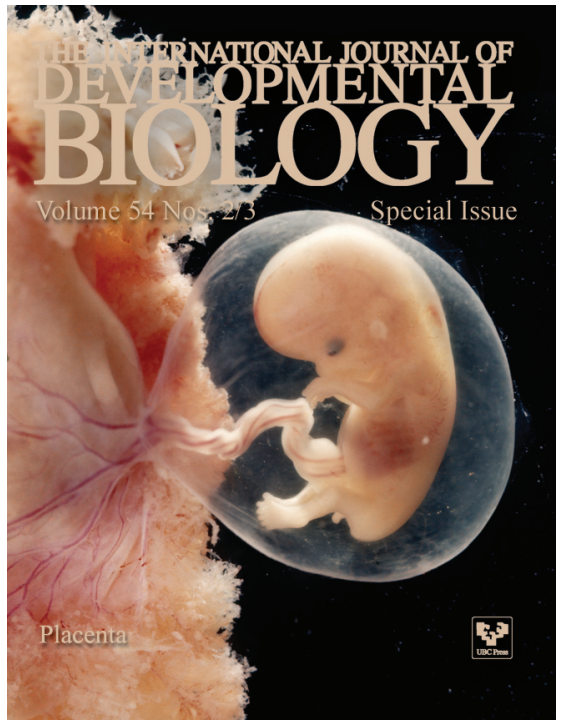

5 yr ISI Impact Factor $(2008)=3.271$

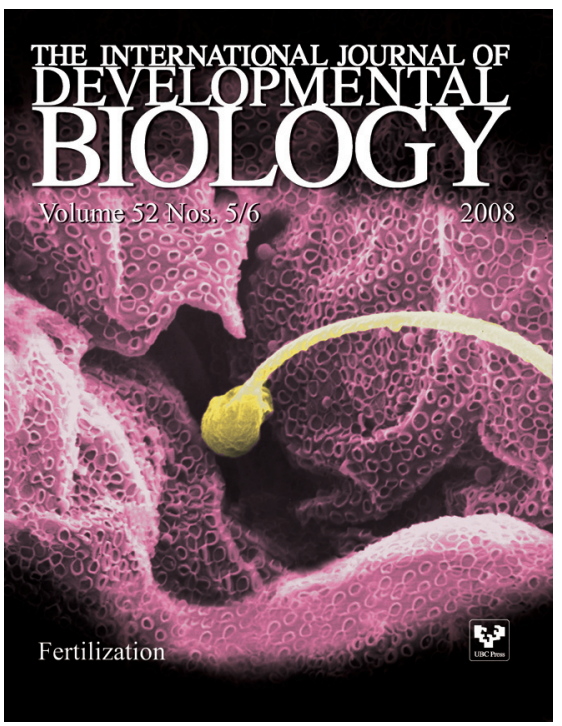

